\title{
UNIVERSITYOF
}

FORWARD

THINKING

WESTMINSTER用

WestminsterResearch

http://www.westminster.ac.uk/westminsterresearch

\section{Exploring the lost television and technique of Fred O'Donovan}

\section{Wyver, J.}

This is an Accepted Manuscript of an article published by Taylor \& Francis in Historical Journal of Film, Radio and Television, 37 (1), pp. 5-23. The final definitive version is available online:

https://dx.doi.org/10.1080/01439685.2016.1272807

(C) 2017 Taylor \& Francis

The WestminsterResearch online digital archive at the University of Westminster aims to make the research output of the University available to a wider audience. Copyright and Moral Rights remain with the authors and/or copyright owners.

Whilst further distribution of specific materials from within this archive is forbidden, you may freely distribute the URL of WestminsterResearch: ((http://westminsterresearch.wmin.ac.uk/)).

In case of abuse or copyright appearing without permission e-mail repository@westminster.ac.uk 


\section{Exploring the lost television and technique of producer Fred O'Donovan John Wyver \\ REVISED DRAFT, 22 September 2016}

In the history of British television drama few notable creative figures are as forgotten as the actor, film director and pioneer producer Fred O'Donovan. After a distinguished career at Dublin's Abbey Theatre, after directing Ireland's first feature film, and after nearly two decades' work on the London stage, O'Donovan joined BBC Television in early 1938. As one of the first directors of studio drama he earned a 'Produced by' credit on more than 60 broadcasts. These included plays by the major Irish writers J.M. Synge, W.B. Yeats, Bernard Shaw and Sean O'Casey as well as dramas by Eugene O'Neill, Chekhov and Molière. Among the actors with whom he worked were Wendy Hiller, Angela Baddeley, James Mason and Alastair Sim. ${ }^{1}$ On his death in the summer of 1952 O'Donovan was 67, and past the BBC's usual age of retirement, but he was still employed full-time by the Corporation. Indeed he had just returned from overseeing a French television adaptation of Daphne du Maurier's Rebecca in Paris.

Along with other television drama producers at that time, including Dallas Bower $^{2}$ and Stephen Harrison, O'Donovan was a key agent in the fledgling form's development. With his background in theatre and the cinema he also exemplified the medium's intermedial engagement with the stage and other media of the day. According to his contemporaries he also worked with a highly distinctive studio style involving lengthy shots without cuts that was known as the 'one camera technique'. But to date no moving image trace has been discovered of what at the time was a celebrated body of work. In part because of this lack of recordings, and despite both his centrality to early television drama and the 'one camera technique' representing a significant aesthetic alternative for studio drama, Fred O'Donovan has received little attention in the literature on early television. $\mathrm{He}$ is a marginal figure in the memoirs of others who were active at Alexandra Palace

\footnotetext{
${ }^{1}$ Details including cast lists of many of O'Donovan's television productions can be found in Screen Plays: The Theatre Plays on British Television database hosted by Learning on Screen, http://bufvc.ac.uk/screenplays/, accessed 25 July 2016.

2 For Dallas Bower, see John Wyver, 'Dallas Bower: a producer for television's early years, 1936-39', Journal of British Cinema and Television, 9:1 (January 2012), pp. 26-39.
} 
before and just after the war ${ }^{3}$, and among later writers only Jason Jacobs in his foundational study of early television drama, The Intimate Screen: Early British Television Drama, has afforded his work sustained attention. ${ }^{4}$ Drawing on a range of written sources, and in particular the records of the BBC's Written Archives Centre (WAC), this article begins the process of recovering O'Donovan's work by offering a critical introduction to his career, an exploration of the production context in which he was operating, and a consideration of the significance of his 'one-camera technique' and its resonances in moving image culture since his death. ${ }^{5}$

The earliest television drama to survive in full in the archives is It Is Midnight, Dr Schweitzer, broadcast live on 22 and 26 February 19536, adapted from Gilbert Cesbron's stage play and directed by the most influential producer from the next generation, Rudolph Cartier. Paradoxically, O'Donovan's feature film Knocknagow, which was released in 1918, has been preserved, albeit in an incomplete form, and has recently been the focus of extensive critical engagement. ${ }^{7}$ The loss of O'Donovan's live television is especially frustrating since he was renowned for a singular approach to studio directing dubbed by his contemporaries as the 'one-camera technique'. Writing in 1950 John Swift distinguished O'Donovan's distinctive strategy from the conventional form of production in which the director used mixes to transition and (when this became technically possible in the mid-1940s) cut between two, three or occasionally four cameras to compose a continuous sequence of shots from different angles and

\footnotetext{
${ }^{3}$ In Michael Barry's From the Palace to the Grove (London: Royal Television Society, 1992), O'Donovan is accorded only a single sceptical paragraph, which is quoted below; Barry is more fulsome in his praise of Bower and George More O'Ferrall.

4 Jason Jacobs, The Intimate Screen: Early British Television Drama, Oxford University Press, 2000, especially pp. 59-63 for Jacobs' analysis of O'Donovan's 1938 production of Juno and the Paycock, which includes a studio plan indicating camera positions.

${ }^{5}$ One peril of writing about O'Donovan is that there is a second Fred O'Donovan (1930-2010), also a theatre and television producer who lived and worked in Dublin; the kinship relationship between them is a subject for further research. ${ }^{6}$ The recording was made during the second transmission; for details see Oliver Wake, BFI Screenonline http://www.screenonline.org.uk/tv/id/1378568/index.html; accessed 12 May 2016.

${ }^{7}$ See especially Issue 33 of the online journal Screening the Past, http://www.screeningthepast.com/issue-33/; accessed 15 May 2016.
} 
with a range of frame sizes. ${ }^{8}$ 'There is one other system,' Swift recorded, 'known as the one-camera technique. It is the speciality of one producer in particular, Fred O'Donovan, who is steeped in stage traditions and to my knowledge has adhered to this method throughout his time as a television producer.'9 As Swift recounted, O'Donovan choreographed his cast in front of just a single camera, which would have had only restricted movement, for scenes lasting 20 minutes or more. 'One-camera production,' Swift continued, 'demands the highest degree of precision and when perfect co-ordination is achieved between cast, cameraman and producer the result is often a smoother and more polished presentation than the more complicated many-angle technique.'10 Swift, like O'Donovan's producer peers before and after the war, clearly regarded this approach as a personal idiosyncrasy, but throughout the first years of the medium it was an active and approved alternative to the dominant multi-camera techniques.

'A new medium finds its place, its identity and its acceptance,' André Gaudreault and Philippe Marion suggest, 'by going through three stages appearance, emergence, and constitution - that mark what we have called its two births. '11 In Britain the 'appearance' stage can be identified as that during which John Logie Baird and others were experimenting with the technology prior to November 1936 when the BBC service began. Gaudreault and Marion develop their generalised argument by asserting

At the moment of its appearance, a new technology is still only a "cryptomedium", because the singularity of the medium is as yet still hidden and unrevealed... By inheriting an apparatus that stands at the intersection of various pre-existing intermedial combinations, the 'crypto-medium' becomes a "proto-medium"... After mimetically relaying its surrounding genres, a medium then unfolds along the path of its singularity. This is the emergent phase. The singular medium becomes the object of claims on its

\footnotetext{
${ }^{8}$ Before the late 1940s transitions between shots initially involved fading down one shot and fading up the next, a process that could take as long as four seconds.

9 John Swift, Adventure in Vision: the First Twenty-Five Years of Television, London: John Lehmann, 1950, pp. 166.

10 Ibid. pp. 167-8.

${ }^{11}$ André Gaudreault and Philippe Marion, 'A Medium is Always Born Twice...', Early Popular Visual Culture, 3:1 (May 2005) p. 12.
} 
identity and is henceforth perceived as virgin territory, as fertile ground for new experiments in communication or artistic creation. ${ }^{12}$

Fred O'Donovan's work in television belongs to this 'emergent' phase, when television was a 'proto-medium', and before its 'constitution' as autonomous and distinct from other media from the mid-1950s onwards. His productions demonstrate both the intermedial combinations and the new experiments in artistic creation that Gaudreault and Marion identify as characteristic of the early, 'emergent' period. More specifically, his 'one-camera technique' is a reminder that the production methods and screen languages that were to become dominant in later years, during the 'mature' years of multi-camera studio drama from the mid-1950s to the early 1980s, were not inherent in the medium from the start. Alternative approaches were developed even if they proved to be roads not taken. Early television, as Doron Galili reminds us was 'a fascinatingly complex period of the medium's social, cultural, and material history, one that saw not only the formation of the dominant traits of 20th-century television but also numerous other alternatives and unrealized possibilities.' ${ }^{13}$ As far as can be ascertained in the absence of recordings, Fred O'Donovan's work was one of those 'alternatives and [his own productions aside] unrealized possibilities'.

\section{Stage and screen in Ireland}

That so little is known of O'Donovan's life is indicated by the online resource IMDb recording (at the time of writing) the year of his birth as 1889. In fact, as his WAC staff file states, Fred O'Donovan was born Frederick George Saunders in Dublin on 13 October $1884 .{ }^{14}$ After he finished his schooling he worked in a land-registry office and in 1908 joined the city's Abbey Theatre as Fred O'Donovan. Founded by W.B. Yeats and Lady Gregory and others, the Abbey had opened its doors less than four years earlier as the home of a new national, modern drama. By 1907, when the theatre witnessed the riotous first

\footnotetext{
12 Ibid.

13 Doron Galili, 'Introduction: Early Television Historiographies', Journal of emedia Studies, 5:1 (2016), DOI:10.1349/PS1.1938-6060.A.473

14 http://www.imdb.com/name/nm0640901/; accessed 15 March 2015; WAC L1/327.
} 
night of J.M. Synge's The Playboy of the Western World, the company had developed a low-key naturalistic style that was suited to the tales of Irish peasant life for which it was becoming known. Contrasting the Abbey's approach with 'the bombastic extravagance to be seen on the commercial English stage,' James W. Flannery has written that 'the simplified but focussed stage blocking, musical delivery and sincere, unaffected deportment of the Irish players all combined to give the company an innocent, slightly exotic charm all its own. ${ }^{15}$ These qualities appear to have been important to O'Donovan and to have shaped his subsequent work as both an actor and a director.

Soon after his debut at the Abbey, O'Donovan was playing leading parts in dramas by Shaw, Synge and Yeats himself, as well as taking the role of Michael Miskell in Lady Gregory's comedy The Workhouse Ward. In the latter he appeared with Arthur Sinclair and Maire O'Neill, and he was also acting regularly with Sara Allgood, with each of whom he would work frequently on the London stage and in television. He toured with the company to Manchester and London and was Christy Mahon in The Playboy of the Western World for the Abbey's successful American tour as 'The Irish Players' from September 1911 to March 1912. He played regularly at the Abbey back in Dublin and was scheduled to perform on 24 April 1916, the night of the Easter Rising, although he took no active part in the rebellion. By this point he had begun to direct for the Abbey stage, and he had also decided to explore the new medium of film. He finally left the company in 1919; as Robert Welch has recounted, 'Fred O'Donovan [...] was looking for more money, his ambitions fuelled, perhaps by the hugely popular success of a film he had made of Knocknagow.'16

Released in January 1918, Knocknagow is a historical drama adapted from an immensely popular nineteenth-century novel by Charles J. Kickham. It was produced by the Film Company of Ireland (FCOI), which had been founded just before the Easter Rising with a nationalist imperative similar to that at the Abbey. The company employed many of the theatre's players and O'Donovan acted in as well as directed several early FCOI films including the multi-reel drama When Love Came to Gavin Burke. Similarly, in Knocknagow he took the role of Arthur

15 James W. Flannery, 'W.B. Yeats and the Abbey Theatre Company', Educational Theatre Journal, 27:2 (May 1975), p. 180.

${ }^{16}$ Robert Welch, The Abbey Theatre: Form and Pressure, Oxford, 1999, p. 75. 
O'Connor, appearing at the start and close of the film but disappearing to America for much of the story. Recognised by Stephen Donovan as 'Irish cinema's first national and international success' ${ }^{\prime 17}$, Knocknagow is set in Tipperary during the land-clearances of the 1840s. Much of it was shot in Charles Kickham's home village of Mullinahone, and it was a conscious attempt to produce a landmark production. As Dan Schultz and Maryanne Felter have written, 'the film version of Knocknagow strategically uses a famous novel associated with the nationalist cause, simplifying the plot and animating and dramatizing individual scenes in order to glorify the land and the Irish peasantry, and send a clear signal that rebellion against oppression was not only right but imminent. ${ }^{18}$

Critical opinion about the film has been divided ever since its first screenings received mixed notices. Variety was especially negative, with its critic dismissing the theatrical qualities of the film as "just "play-acting," all the way, with no illusion to make the spectator believe he is witnessing anything more than a company of actors, impersonating human beings.'19 The unwieldy and at times baffling narrative of the adaptation has also attracted criticism, although Stephen Donovan proposes a more sympathetic response:

While the sheer difficulty of compressing Kickham's sprawling tale was likely compounded by the company's relative inexperience in filmmaking, the FCOl's adaptation is best understood as an attempt to give audiences a filmic version of the novel as they knew it, that is, as a loose collection of memorable characters and situations. ${ }^{20}$

And while recent critical writing has approached the film from a variety of angles, including exploring its use of landscape and of folk songs, there has been little consideration of O'Donovan's direction. Control of the overall narrative may have eluded him, but he draws convincing performances from a large cast. Moreover, Charles Barr has suggestively explored ways in

\footnotetext{
17 'Introduction: Ireland's own film', Screening the Past 33, http://www.screeningthepast.com/2012/02/introduction-ireland\%E2\%80\%99sown-film/, accessed 5 May 2016

18 'The making of an Irish nationalist: James Mark Sullivan and the Film Company or Ireland in America', Screening the Past 33, http://www.screeningthepast.com/2012/02/the-making-of-an-irish-nationalist/, accessed 5 May 2016.

19 Variety, 30 September 1921, p. 35

20 Donovan, op cit.
} 
which O'Donovan's use of the camera anticipates the technique of his television productions:

For much of the film's length, O'Donovan focuses on conveying maximum information and affect without cutting within scenes, or moving the camera, rather in the manner of the early work of D.W. Griffith (ahead of Birth of a Nation) or of Victor Sjostrom in Sweden, both of whom had, like him, long experience in theatre. [...] Barr highlights a single-shot introductory scene, the first meeting between two couples, and an encounter on a country lane, and argues that in each one senses a real exploratory relish in covering so much in single shots, and in handling space and movement in a variety of ways, the composition and movement being successively diagonal, lateral, and direct towards camera. Impressive in a different way is the much slower, solemn three-minute interior scene, much later in the film, around the bed of the youthful Norah Lahy, who is dying from tuberculosis. [...] The mise-en-scene is very precise, incorporating important background detail and some movement of characters around the bed; O'Donovan is again clearly drawing on his Abbey Theatre staging experience while exploiting the greater closeness and control of viewpoint enabled by cinema. ${ }^{21}$

\section{Acting in England}

If Fred O'Donovan hoped after his departure from the Abbey that the FCOI would be a new professional home, he was quickly disillusioned, since the film company went bankrupt in 1920. For the next two decades he earned his living as an actor in numerous productions on the London stage and elsewhere. His first post-war appearance in the capital appears to have been reprising his celebrated Christy Mahon in a revival in July 1921 of The Playboy of the Western World by 'the Irish Players' (although any formal relationship to the Abbey at this point appears to have been distant). O'Donovan did, however, have with him former

${ }^{21}$ Charles Barr, 'Fred O'Donovan: not just Knocknagow', Film Ireland, 12 September 2016, http://filmireland.net/2016/09/12/fred-odonovan-not-justknocknagow/; accessed 22 September 2016. 
Abbey stalwarts Maire O'Neill, Sara Allgood, Arthur Sinclair, Harry Hutchinson and Sidney Morgan. Following this run, the Irish Players appeared on numerous occasions in London and Manchester, giving Playboy, The Plough and the Stars, Juno and the Paycock and Lennox Robinson's The White-Headed Boy. O'Donovan also took on a wide variety of roles for other theatrical managers, playing in Shakespeare, Marlowe, Shaw, Galsworthy, Pirandello and Chekhov as well as in plays by contemporary writers, and also occasionally directing productions. But he returned time and again to Irish drama, including a 1934 Juno and the Paycock revival with former Abbey players Hutchinson, O'Neill, Sinclair and Kathleen Drago. By now he was also securing occasional roles in British feature films including Henry Edwards' comedy General John Regan (1933) and Ourselves Alone (1936, d. Brian Desmond Hurst), a love story set at the time of the 1921 Anglo-Irish war also including O'Neill and Tony Quinn. 1936 also saw Donovan's radio debut, with the small part of a labourer in The King of Spain's Daughter, a play by Irish writer Teresa Deevy. Radio, however, only became central to his working life after the television service shut down in early September 1939.

'"A play a day" was the target we set ourselves at the outset,' recalled Cecil Madden in his memoir of the early months of BBC television from Alexandra Palace. ${ }^{22}$ The service went on air on 2 November 1936 and in pursuit of Madden's aspiration it opportunistically presented whatever elements of London theatre it could coax in front of the cameras, with at least one drama shown each week. Lady Gregory's one-act The Workhouse Ward, billed in the Radio Times as a production by 'The Irish Players', with a cast of Kathleen Drago, Tony Quinn and O'Donovan, went before the cameras on the afternoon of 28 December. Exceptionally, for such re-presentations on television were rare, the production was given again for the screen in January, August and December 1937. On each occasion O'Donovan took the role of Michael Miskell which he had first played on the stage of the Abbey almost thirty years before. Of the later December broadcast, The Times wrote:

${ }^{22}$ Cecil Madden, Starlight Days, ed. Jennifer Lewis, London: Trevor Square Productions, 2007, p. 104. 
Here was a play finely acted and admirably suited to the television screen because of its intimate atmosphere. We were in the workhouse ward with the two old vagabonds and we could note every emotion fluttering across the features of Fred O'Donovan or Harry Hutchinson [who had replaced Tony Quinn] as they quarrelled deliciously together. It was the whole play, visual and aural, in a way that sound alone can never be. ${ }^{23}$

During 1937 O'Donovan appeared on television on several other occasions, including taking a small role in March in Lady Gregory's The Rising of the Moon, just as he had in Dublin in March 1908, and also playing Oliver Goldsmith in Nino Bartholomew's one-act comedy April Showers. ${ }^{24} \mathrm{His}$ appearance as the King of Hearts in George More O'Ferrall's studio production of Alice in Wonderland on Christmas Day 1937 was the actor's final appearance in front of the cameras before the war.

\section{Producing pre-war}

At the end of 1937 Fred O'Donovan was invited to apply for one of two newly created producer posts within the television service. His application was initially turned down since it arrived just after the closing date, but director of television Gerald Cock requested that this decision be overturned. ${ }^{25}$ After two meetings at Broadcasting House, assistant controller of programmes D.F.L. Wellington, recorded, 'I certainly think he is worth trying. He hasn't as flexible a mind as the man I saw on Wednesday (Barry) but I rather like his sober good sense. ${ }^{26}$ The other successful candidate was Michael Barry, who would go on to be Head of Television Drama in the 1950s and oversee some of the BBC's major drama projects including An Age of Kings (1960) and The Wars of the Roses (1965). Within the first year he had made a very good impression with his new masters, and for his first internal review Gerald Cock noted that his work had

\footnotetext{
23 'The Tragic Muse', The Times, 3 January 1938, p. 19.

24 First broadcast on 20 April 1937, April Showers has a good claim to be the first original drama written for television. No trace of a previous theatre or radio production can be found.

${ }^{25}$ Gerald Cock, handwritten addition to file copy of letter dated 2 December 1937, WAC LI/327.

${ }^{26}$ D.E.L. Wellington to D.H. Clarke, 'F. O'Donovan', 21 January 1938, WAC $\mathrm{LI} / 327$.
} 
been 'Very good... with excellent ideas and with a long and varied experience. ${ }^{27}$ After an initial training period, Fred O'Donovan's first production was a presentation on 5 April 1938 of Sean O'Casey's one-act The End of the Beginning, with his Workhouse Ward partner Harry Hutchinson in a key role. After this, in the pair of small studios at Alexandra Palace he produced (which at the time meant directing both actors and cameras) a play roughly once every four weeks. He oversaw ten productions between April and December 1938 and eight in the eight months of the television service's operation in 1939. Only three of the later ones were from scripts written especially for television, including Yvette Piene's The Fame of Grace Darling (9 July 1939) and Fox in the Morning by Lionel Brown (30 July 1939). What is striking about the other sixteen productions is how the choice mirrored stage productions with which O'Donovan had been previously involved. Moreover, the majority of the productions were of scripts by Irish authors with which he was familiar from his time at the Abbey, including two plays by O'Casey, one each by Yeats and Synge, and a drama written by Lady Gregory as well as two of her adaptations from Moliere.

The high proportion of plays that O'Donovan is known to have acted in or produced previously indicates how in these first years of the medium the producer was able to determine to a significant degree which dramas were produced. As a consequence of this freedom O'Donovan was able to carry across to this new medium his commitment to modern Irish drama. After the war the number of Irish plays with which he was associated was far smaller and the playwrights whose dramas he staged were significantly more diverse. Yet even then his productions included Synge's The Playboy of the Western World (9 August 1946) and The Shadow of the Glen (17 March 1948) as well as Yeats' The Player Queen (5 December 1946) and two plays by Lennox Robinson, Is Life Worth Living? (17 March 1949) and The White-Headed Boy (2 October 1951). There is every sign that O'Donovan post-war was keen to work on prestigious dramas by Chekhov, Shaw and Eugene O'Neill, but the range suggests that his personal preferences perhaps counted for less as choices were increasingly determined by departmental executives. Casting similarly indicates that O'Donovan was able, at least in the pre-war years, to exercise a significant influence. When he came to

${ }^{27}$ Gerald Cock, 'Confidential report', 2 January 1939, WAC LI/327. 
present Juno and the Paycock on 21 October 1938, Maire O'Neill played Juno, Harry Hutchinson was Captain Jack Boyle and Tony Quinn was 'Joxer' Daly, just as they had been in his stage revivals. Hutchinson and Quinn also appeared in several of O'Donovan's television productions. Distinguished by the contributions of these trusted colleagues, O'Donovan's initial productions were greeted with positive reviews. Of his presentation of Yeats' mystical verse play Deirdre (9 May 1938), The Times wrote that it was 'staged by Mr Fred O'Donovan in the style of an ancient saga come to life, beautiful to look at and to listen to, remote and not too strange. ${ }^{28}$ General John Regan was hailed by The Observer's television critic as 'the most laughter-provoking thing that television has yet given.'29 And in May 1939, only just over a year after O'Donovan had begun producing television drama, The Times similarly enthused about his production of George Grimaldi's original drama Behind the Schemes (27 May 1939) that it 'did not have a dull moment... Mr Fred O'Donovan thinks in terms of his cameras, which means that viewers never think of them, but only of the story, and his production had pace and clarity. ${ }^{30}$

Jason Jacobs suggests that by 1938 there was a standard means of organising space, cameras and the production process for drama in each of the two studios at Alexandra Palace:

[O]ne studio divided into three sets, with a main set at one end of the studio where the majority of the dramatic action would take place, and two others dispersed either at the other end or along the sides (perhaps with some auxiliary sets and a caption-board area). These areas were covered by four cameras, two of which were mobile and covered action on the main sets. One other camera was used for 'special' shots (possibly close-ups, or brief scenes away from the main sets), and a fourth camera was reserved for captions. ${ }^{31}$

In O'Donovan's presentation of Juno and the Paycock he employed two cameras to cover what in the theatre is the main set of a living room. A third camera

28 'Broadcasting and Television: Notable Performances', The Times, 23 May 1938 , p. 8.

29 'E.H.R.', 'Television', The Observer, 20 November 1938, p. 13.

30 'Televised Plays', The Times, 5 June 1939, p. 10.

31 Jacobs, op cit., p. 43. 
covered two subsidiary sets of a hallway and a bedroom, as well as being used for captions, while a fourth was employed for what appeared to be exterior shots of the house. The broadcast attracted particular attention, being praised by the critic for The Times as indicating how television drama ought to develop:

Skilful use of the mobility of the cameras allowed shots to be taken of the adjoining room, and of the street door, and of the funeral procession passing by. The future of television seems to lie in extending the stage in this way, and emancipating the production from stage conventions. ${ }^{32}$ Yet this approach towards 'emancipation' away from the theatrical and towards the cinematic was considered distracting by Grace Wyndham Goldie in The Listener:

Television plays are doing marvellously. But there is increasing danger in this business of imitating the methods of film. The other night a producer nearly ruined a finely acted performance of Juno and the Paycock through trying to give it the continuity which is good in television by unnecessary bits of sight. Again and again he spoiled the effect the playwright intended by making us see unnecessary things, a man knocking instead of merely letting us hear the knock, a procession passing instead of merely letting us see the singing. ${ }^{33}$

While The Times critic saw the future of television drama as requiring the integration of filmic techniques, for Goldie these clashed with the desired 'theatrical' impression, which she claims O'Casey would have been preferred. Discussing Juno and the Paycock, Jacobs suggests that the prologue in particular, invented by O'Donovan and detailed in the television script, 'demonstrates the slippage [in early television drama] between the cinematic, the theatrical, and the live radio broadcast'. 'It supports,' Jacobs writes, 'the hypothesis that early television drama was a hybrid, a unique but structured mixture similar to other forms of presentation and representation familiar in radio, theatre and the cinema. ${ }^{34}$ What was suggested by the critic for The Times, however, may be recognised as what Gaudreault and Marion in the 'emergent

32 'Modern Poetry: A Broadcast Recital', The Times, 24 October 1938, p. 8.

33 'Television: Cyrano de Bergerac', The Listener, 10 November 1938, p. 1029.

34 Jason Jacobs, op cit., p. 60. 
phase' of a medium identify as television 'unfold[ing] along the path of its singularity. ${ }^{35}$

By late August 1939, when the television service was preparing to shut down as soon as war was declared, it had been decided that O'Donovan should be attached for the duration to the repertory company of actors for the features and drama departments. He worked primarily as an actor until the summer of 1941 when he was transferred to the radio drama department in London as a producer, although the head of radio department, Val Gielgud, appears to have been somewhat grudging in his recognition of O'Donovan's contributions. At the end of 1943, for example, Gielgud's internal report read in full: 'A good year's work. He is always thorough, conscientious and efficient.' ${ }^{36}$ The following year O'Donovan was granted leave for three months from April to appear on the West End stage in a production of The Last of Summer by Kate O'Brien and John Perry, and then in early 1946, pausing only to mount Juno and the Paycock for radio with Maire O'Neill, he rejoined the television service as it started up operations once again. But by this point he was two years beyond the statutory age of retirement, and from then on, while executives valued his experience on the studio floor, the BBC renewed his contract for only a year at a time.

\section{After the war}

Between 1946 and 1950, Fred O'Donovan produced between eight and eleven dramas each year from Alexandra Palace, as well as taking occasional roles in presentations by his colleagues. His first post-war production was Chekhov's The Proposal (18 June 1946) and later in the year he took on ambitious broadcasts of Eugene O'Neill's Anna Christie (23 July) and Shaw's Candida (6 October). At the end of the year he was entrusted with one of the most prestigious slots in the schedule, mounting Noel Coward's Hay Fever as the Christmas Day evening drama. In 1948 his production of James Bridie's Dr Angelus (11 April) was especially praised internally, and led to the award of a $£ 50$ bonus. The BBC drama executives had been keen to broadcast a version of the theatrical staging of Bridie's play in which Alastair Sim had delighted critics and

\footnotetext{
35 See note 7 above.

${ }^{36}$ Val Gielgud, 'Annual Confidential Report', 29 December 1943, WAC LI/327.
} 
audiences. Sim was seen as crucial to the success of a television translation, and O'Donovan was selected as the producer by head of television programmes Cecil McGivern because 'his one camera method would be much more easily grasped by Sim. [Robert] Atkins (ex-films) uses a much more complicated method and relies of quick camera manoeuvring and fast cutting. ${ }^{37}$ When the play was broadcast it carried the credit 'Based on the stage production by Alastair Sim' and one production memo noted that in the studio 'relations between Sim and O'Donovan were extremely delicate'. ${ }^{38}$ Even so, Norman Collins (Controller, Television) wrote to O'Donovan that the broadcast was 'a most excellent production. Really outstandingly good. ${ }^{39}$

In Fred O'Donovan's 1948 'Annual Confidential Report', Robert MacDermot was effusive:

Mr O'Donovan has kept up an extremely high standard of production and during the past year has added to his laurels with plays of all kinds. Two in particular, employing the 'one-camera' technique, which is practically O'Donovan's trade-mark, were chosen for repeat among the three most popular plays of the year. He is of great value to television and can be trusted with an assignment of practically any kind. ${ }^{40}$

Eighteen months later, however, MacDermot's successor, Val Gielgud, was more circumspect in his confidential assessment of O'Donovan's capabilities when he wrote, 'An excellent, reliable and steady - if faintly unimaginative producer.' ${ }^{41}$ This judgement on O'Donovan followed one of his most notable successes, a largescale production of The Scarlet Pimpernel (5 February 1950). 'The Scarlet Pimperne/ was unexpectedly good', enthused the radio critic of The Manchester Guardian. 'Somehow the cramping limitations of television dissolved a little before Fred O'Donovan's clever production. If neither the French Revolution nor the British aristocracy had much room for manoeuvre, the most skilful use was made

37 Memo, 'Dr Angelus and Alistair (sic) Sim', 9 February 1048, WAC T5/147.

38 Robert MacDermot, Memo, undated but with handwritten annotation 16.4.48? sic], WAC T5/147.

39 Memo, 13 April 1948, WAC T5/147.

4025 January 1949, WAC T5/147.

415 June 1950, WAC T5/147. 
of settings and groups.' 42 In an internal memo responding to a query about the play being produced with one camera, Norman Collins wrote

Just for the purposes of record let me please put down in black and white that in reality [Pimpernel] was produced with 7 cameras and in 2 studios. All that was single camera was the technique. ${ }^{43}$

As Collins was at pains to explain, each of the cameras had been used by O'Donovan for lengthy developing shots in separate sets spread across both Alexandra Palace studios. It was seemingly about this production that Cecil Madden recalled:

We did a very fine production of The Scarlett (sic) [Pimpernel] [...] we'd spent an awful lot of money, so we decided to film it. We put a film camera in front of the monitor and filmed it all. It wasn't satisfactory, because of course you could see the lines, but it was something. The following morning I got a phone call from Sir Alexander Korda, who said "I understand you have infringed my rights by making a film of the Scarlett Pimpernel."... He further said, "you will take your negative, and your positive, out into the open air in front of Television Centre and you will burn them, and you will film them being burned so that I will know that you have done it. And we did it. 44

Madden's memory tripped him up over the details, since this was well before Television Centre was in use, but this is a resonant story given that every other O'Donovan production is also 'lost'. In an internal memo Norman Collins noted that, "It should be remembered that this is the first time that we have asked for a full-length play to be recorded. ${ }^{45}$ There are also memos recording an extensive discussion about repairing parts of the sound on the recording that had been missed on the night. But then on 20 March 1950 Collins wrote,

I have returned from a week's leave to find that on Mr Welford's advice a sample recording of The Scarlet Pimperne/ had been destroyed, to avoid

42 'Boxing and Judo', The Manchester Guardian, 13 February 1950, p. 5.

43 Memo, 13 February 1950, WAC T5/449

${ }^{44}$ Cecil Madden, Starlight Days, ed. Jennifer Lewis, London: Trevor Square Productions, 2007, pp. 261-2; following Bruce Norman in Here's Looking at You: The Story of British Television 1908-1939, Royal Television Society, 1984, revised 2004, p. 134, Jacobs, op cit., p. 12 mistakenly dates the production of The Scarlet Pimpernel and Korda's intervention to 1939.

45 Memo, 23 February 1950, WAC T5/449 
what was represented to the Service as a threat of legal action. I deplore this. 46

This memo confirms that tele-recording was technically feasible, even if not entirely 'satisfactory' in Madden's eyes, a full three years before It Is Midnight, Dr Schweitzer from February 1953, which is believed to be the earliest archival survival. The legal argument may have led to further caution about the deployment of the technology, but it seems remarkable that no further recording of drama, either in extract or at full-length, is known from before February 1953; one can only hope that the archives contain undiscovered treasures from this period. ${ }^{47}$ Jacobs, however, identifies three further constraints on the use of recording technologies in these years: 'the limit of aesthetic horizons [by which I take him to mean that television was not regarded as sufficiently interesting to see again]; copyright controls on recording material [as with The Scarlet Pimpernel]; talent unions' agreements with the BBC.'48

Three years before The Scarlet Pimpernel, a writer for Radio Times described how Fred O'Donovan as a former stage director intended to treat Stanley Houghton's play Hindle Wakes (6 July 1947). '[He] believes,' the correspondent wrote, 'in showing the action of a play as it is seen by a single member of the audience. Instead of cutting or "mixing" from one camera to another, following the artists as they move about, he prefers to stick to one camera for any set scene. ${ }^{49}$ O'Donovan himself elaborated: 'Mind you [...] this means much more work at rehearsals and it is more exactlng in that the cast have to be grouped to suit the camera position, but I do contend that this method makes for a smoother and sometimes more polished performance. 50 This distinctive 'one-camera technique' was outlined in an interview given by the critic Roger Manvell published in 1953:

\footnotetext{
46 'Telefilm drama recordings', 20 March 1950, WAC T5/449

47 The film documentary Television is Here Again!, produced to mark the return of the service in the summer of 1946, includes what appears to be a reconstruction, specially shot with film cameras, of an extract from a pre-war production of The School for Scandal.

48 Jacobs, op cit., p. 10.

49 'Television: By Gum, it's Wakes Week', Radio Times, 4 July 1947, p. 29.

50 Ibid.
} 
[Fred O'Donovan] did not favour using a series of cameras, cutting from one to the other. Nonetheless, he managed to get great variety into each act of the play he was directing. In effect he developed Hitchcock's tenminute take into a half-hour take! He either arranged his artists so that they came up to the camera for a close-up, or he trucked the camera into the action for close-ups or medium shots. ${ }^{51}$

Manvell employs here the cinematic comparison with Hitchcock's 1948 film Rope, based on Patrick Hamilton's stage play, and shot in just 10 developing takes of up to 10 minutes each. ${ }^{52}$ By contrast a colleague of O'Donovan's, designer Richard Greenough, regarded the technique as insistently theatrical. In a 1990 interview he recalled:

I thought [Fred O'Donovan] was marvellous. He had the theory that if you went to the theatre you sat in the best seat you could afford, preferably in the stalls a few rows back, and all his plays he did on one camera per scene - so you weren't cutting at all, but he did it brilliantly; If someone came in the room he'd be on them, then follow them across to pick up the next person, who he then spoke to, then he might follow him back to somewhere and the whole thing flowed beautifully.... You never knew you were only on one camera because the whole thing flowed. ${ }^{53}$

In a short obituary published in Radio Times Michael Barry recalled O'Donovan's approach when he noted that 'by reducing the mechanical complication to a minimum he obtained a smoothness and a serenity that became the O'Donovan hallmark upon the screen. ${ }^{.54}$ But Barry was rather less complimentary in his 1992 memoirs, when he wrote

He was a superb director of actors but not as young as some of us. With the passing of time he became less inclined to move swiftly about the rehearsal room observing the actors from the different positions of the

\footnotetext{
51 'BBC-TV: An Interview with Roger Manvell', The Quarterly of Film Radio and Television, 7:3 (Spring 1953), p. 258.

52 Another connection with Hitchcock is that in 1929 the celebrated film director made his own adaptation of O'Casey's play Juno and the Paycock with former Abbey Theatre players Barry Fitzgerald, Maire O'Neill and Sara Allgood. 53 My thanks to Leah Panos for this reference in the BECTU Oral History interview with Richard Greenough, recorded in 1990.

54 Michael Barry, 'Fred O'Donovan, 1884-1952', Radio Times, 1 August 1952, p. 35.
} 
cameras. The time arrived when he preferred to sit. Planting his chair in the central position he would beckon all the action to take place before him. There were those who found nothing to criticise in this method. One reviewer hailed it as an innovation, and established the phrase 'one camera technique'. 55

His peers like Greenough recognised it as a 'theatrical' approach, although it clearly also has links with the tableau style of early cinema as well as Hitchcock. Michael Barry, however, punctures such an elaboration of connections by suggesting that it was at least partly accounted for by O'Donovan's fatigue in his advancing years.

The autumn of 1950 saw Fred O'Donovan's adaptations of Vanity Fair (3 September 1950) and The Strange Case of Dr Jekyll and Mr Hyde (14 November 1950) and early in the new year he mounted The Scarlet Pimpernel again (14 January 1951). Soon after this he entered hospital for an operation to remove a duodenal ulcer. Internal criticism of his work was growing with Cecil McGivern writing to the head of drama criticising the re-presentation of The Scarlet Pimpernel for 'its feeling of cramped space, the various slips... the only average acting in the supporting parts; the almost complete absence of gloss, polish and finish.' 'It is not real television at all,' he concluded. ${ }^{56}$ To which Val Gielgud responded with a remarkable critique indicative of his dissatisfaction with O'Donovan and what was increasingly seen as an old-fashioned approach:

When you ask whether I consider this to be Television, the answer is, I think, that it is one form of Television. It is the nearest approach you can get in a theatre of a presentation of this kind and this kind of play, which will always have a great appeal for a fairly moronic audience. In terms of ethics or in strict terms of Television drama, it has neither significance nor value. ${ }^{57}$

Fred O'Donovan was on sick leave from February to the end of May, and after he had returned to work it is clear from internal memos that his health gave continuing cause for concern. Nonetheless he scored a singular success with To

\footnotetext{
55 Michael Barry, From the Palace to the Grove, London: Royal Television Society, 1992, p. 30.

56 Cecil McGivern, 'The Scarlet Pimpernel', 17 January 1951, WAC T5/449.

57 Val Gielgud, 'The Scarlet Pimpernel', 22 January 1951, WAC T5/449.
} 
Live in Peace, written by and starring Victor Rietti (27 November 1951), which one critic described as 'one of the best television productions there has ever been.' 'Fred O'Donovan's production,' the review continued, ' was remarkably single-minded (or perhaps rather single-eyed) and created a placid and unfussy atmosphere. ${ }^{58} \mathrm{He}$ was again entrusted with the Christmas Day drama, producing this time J.B. Priestley's When We Are Married (25 December 1951), and after producing three further dramas in the first half of 1952 he travelled to Paris for what would prove to be his final production, Rebecca.

In early 1952 the BBC was preparing a week of programmes in July to be broadcast from Paris via a new cross-channel link. During the early discussions for this, Fred O'Donovan was invited to Paris to produce a television play. In a memo to Norman Collins, Controller, Television Programmes Cecil McGivern noted that the director-general of the French television service Wladimir Porché 'has asked personally that O'Donovan should be allowed to go to Paris to demonstrate his one camera method in the French television studios. ${ }^{59} \mathrm{M}$. Porché apparently believed that Fred's 'one camera' technique could offer 'a most important "lesson" for the French Television producers and technicians'. Rebecca was broadcast in French on 9 June and again on the following day and was the subject of an extended sympathetic review by Janick Arbois in Radio-CinemaTélévision. Noting that the staging of the play took place in a set that included three rooms in a row 'in which the camera moved with surprising flexibility', Arbois described the use of the single camera for extended scenes and contrasted this with the usual multi-camera approach. For Arbois, O'Donovan's approach suggested the possibility of a televisual form that was entirely appropriate for the theatre on the small screen 'The broadcast of Rebecca,' she wrote, 'regardless of the fact that this was only a poor skeleton of the novel, and regardless of some unconvincing performances - brought us the revelation of a true theatre television.' Whereas in the cinema (and she too referenced Hitchock's Rope) this technique might seem gratuitous, here it proved to be 'in terms of televised theatre, a real aesthetic invention.' The continuous focus of a single camera heightened the intensity of the play, and she highlighted the impact of one scene:

58 'To Live in Peace', The Manchester Guardian, 5 December 1951. p. 5. 59 Memo from Controller, Television Programmes, 14 January 1952, WAC L1/327. 
The scarcity of close-ups made the ones that were used more significant and more moving. I think the slow progress towards the faces of Maxim de Winter and his wife resulted in a beautiful composition, delayed at first, and then when it was achieved, it felt like a culmination of the drama.

Fragmented and thrown in pieces on the screen, its force would have been quite different.

Arbois recognised that this technique was not suitable for all transmissions but she felt that it suggested a way forward for theatre on television:

The mixing of several cameras remains, unquestionably, the way for outside broadcasts, of various scenes where the viewer's curiosity must be satisfied in every moment, where surprise is one of the rules of the game. But you cannot treat a piece of theatre as a sports report or a broadcast from a music hall. The experience of Rebecca has taught us that, which is already a significant step towards elaborating an original art of television. ${ }^{60}$ One of the last of O'Donovan's productions was Lennox Robinson's The WhiteHeaded Boy broadcast on 2 October 1951, in which O'Donovan also acted. The Viewer Research Report for the broadcast records a 73 Reaction Index, was above the current average of 67 for plays. The report continues

The production was described as well-done on the whole. Some of the scenes, however, were said to have been rather crowded - "actors tended to be heaped around the table" wrote one viewer, "at times the whole family appeared to be attempting to look through the same keyhole. ${ }^{61}$ Tucked away in the production file for The White-Headed Boy there is a note that is rather more precise about the formal approach to the production and that is revealing about both O'Donovan's technique and television more generally at a moment when, to use the words of the pre-war Times review of Juno, the medium was at last beginning to 'emancipate' itself from stage conventions. In an internal memo, Head of Drama Val Gielgud wrote of the production that it seemed to me never to get away from a photographed stage play in which the screen was hopelessly cluttered up by too many characters... has not the moment come for us very seriously to think whether the time for the

60 J. Arbois, 'La caméra unique: est-elle l'avenir du théâtre télévisé?' RadioCinema-Télévision 127, 15 June 1952, p. 9; the translations are by Wyver. 61 Viewer Research Report, 24 October 1951, WAC VR/51/416. 
O'Donovan single camera technique has not in fact passed? I know its record has been creditable but it does seem to me that it has really outworn the development of the medium in other directions. ${ }^{62}$ Gielgud most certainly did not see O'Donovan's unique style as, in Janick Arbois' words, 'a significant step towards elaborating an original art of television.' For him it was backward looking, rooted in theatre and inappropriate for the autonomous form of television towards which he was looking. Gielgud's remarks also underscore how O'Donovan's work exemplifies both the 'new experiments' and especially the 'intermedial combinations' suggested by Gaudreault and Marion as typical of a medium at the stage of development that television then was. But Gielgud was committed to a 'path of singularity' for his medium that needed to leave behind these combinations. For Gielgud, with a vision of television needing to develop as a specific and distinctive medium, which he understood to depend at least in part on increasingly complex, faster-cut and more visually sophisticated studio techniques, O'Donovan was a relic of a past to be transcended.

In contrast to Gielgud's dismissal, in the early 1950s an engagement with cinema's long takes and developing shots and of their relationships to the world in which we live was emerging as a central critical concern in the writing of André Bazin. ${ }^{63}$ Although this simplifies the complexities of Bazin's thought, in the words of Girish Shimbu 'the long take [for Bazin] was ideally suited to capture the rhythms and complexities of reality, while preserving its unity in space and time. ${ }^{64}$ Since O'Donovan's pioneering work, a number of television directors have employed extended single shots in both studio and location-shot dramas. Michael Barry noted that O'Donovan's technique was later 'rediscovered by the eager Dennis Vance'65. Dennis Vance was a producer with BBC Television before in 1955 becoming Head of Drama at

\footnotetext{
62 Val Gielgud, Memo, 9 October 1951, WAC T5/581.

63 Bazin was a colleague of Janick Arbois and wrote regularly on television as well as cinema for Radio-Cinema-Télévision, although he did not write about Rebecca; see Dudley Andrew, ed., André Bazin's New Media, Berkeley: Los Angeles and London: University of California Press, 2014.

64 Girish Shimbu, 'The long take', girish, 2006, http://girishshambu.blogspot.co.uk/2006/07/long-take.html; accessed 25 July 2016; for a further discussion of Bazin's ideas, see Brian Henderson, 'The long take', in Bill Nichols, ed., Movies and Methods, Berkeley: Los Angeles and London: University of California Press, 1976, pp. 314-324.

65 Barry, From the Palace to the Grove, op cit., p. 30.
} 
ABC where he oversaw the creation of Armchair Theatre (1956-74). Very few studio productions directed by Vance survive, but Mark Duguid has celebrated 'an unusually fluid camera style [and] elaborate tracking shots' in the Armchair Theatre production of Eugene O'Neill's Emperor Jones (March 30 1958), which was directed by Ted Kotcheff. ${ }^{66}$ John Hill has discussed the exploration by studio director Anthony Pélissier in the BBC dramas The Sleeping Clergyman (11 January 1959) and The Torrents of Spring (21 May 1959) of 'the potential of one camera to one scene'. 'The circumstances of live transmission,' Hill observes, 'meant that the adoption of this technique involved the elimination of cutting during a scene. ${ }^{67}$ Subsequently, director Alan Clarke made powerful use of long continuous takes, often achieved with Steadicam camera mounts, in his film dramas for television, including in his study of a racist skinhead, Made in Britain (Central/ITV, 1983) and Elephant (BBC, 1988), depicting 18 casual shootings in Northern Ireland. The latter consists, as Nicholas Rapold has written, simply of 'a series of long Steadicam takes without any exposition or narrative, and almost zero dialogue. '68 Producer Christopher Morahan recalled that even in his early studio dramas Clarke's visual style was often 'very still, rather emblematic he would hold a frame for a very long time because the life was in the frame. ${ }^{69}$ Numerous cinema directors have also employed long takes featuring extended developing shots including Jean Renoir, Orson Welles, Kenji Mizoguchi, Jean-Luc Godard, Miklós Jancsó, Theo Angelopoulos, Bela Tarr and Hou Hsiao-Hsien. ${ }^{70}$ And in relation to the emerging hybrid form of live cinema broadcasts of theatre productions, brought forth by

\footnotetext{
66 Mark Duguid, 'Armchair Theatre 1956-74)', BFI screenonlone, http://www.screenonline.org.uk/tv/id/534786/; accessed 22 September 2016. 67 John Hill, '"Creative in its own right": the Langham Group and the search for a new television drama', in Laura Mulvey and Jamie Sexton eds., Experimental British Television, Manchester University Press, 2007, p. 20.

68 Nicholas Rapold, 'Alan Clarke', Senses of Cinema 37, http://sensesofcinema.com/2005/great-directors/clarke/; accessed 22

September 2016.

69 Quoted in Richard Kelly ed., Alan Clarke, London: Faber and Faber, 1998, p. 80.

70 The literature on the long take in cinema is extensive; one place to begin is David Bordwell, 'Stretching the shot', Observations on Film Art, 2012, http://www.davidbordwell.net/blog/2012/10/07/stretching-the-shot/; accessed 25 July 2016.
} 
initiatives like NT Live and RSC Live from Stratford-upon-Avon, there is an active debate about the appropriate balance between shots that stand back from the stage, regarded by some as more appropriately 'theatrical' in that they allow performances to be better appreciated as the action unfolds within a single frame, and a more insistently 'cinematic' use of rapid cutting between close-ups. ${ }^{71}$ Even if we have no visual record of his productions, Fred O'Donovan's concerns continue to resonate with vital aspects of the moving image today.

On his return from Paris in mid-June 1952 Fred O'Donovan had planned to direct again for the West End stage and to make a trip to Dublin, the city of his birth, to contribute to a Radio Eireann broadcast and to meet actors for a forthcoming BBC production of a new play. ${ }^{72}$ But he was taken ill and readmitted to hospital where he died on 19 July. His Times obituary three days later runs for some 50 lines. ${ }^{73}$ His work in films goes unmentioned, and just two and a half lines are devoted to television. For The Times and its readers Fred O'Donovan was a much-loved stage actor and his important work as an innovative pioneer in a medium that was as-yet 'unemancipated' and as an exemplar of its early hybridity went unmentioned. By virtue of it never having been recorded Fred O'Donovan's television was already 'lost' - and the process of forgetting his use of a hallmark technique had already begun.

\section{Acknowledgements}

This article was written as part of the AHRC-funded research project Screen Plays: Theatre Plays on British Television (2011-15). Many thanks to the reviewers, and to my colleague $\mathrm{Dr}$ Amanda Wrigley, for their valuable and helpful suggestions. I am also most grateful to the staff at Caversham, and especially archivist Louise North, for her help, and also to Mairéad Delaney, archivist at the Abbey Theatre. I owe a particular debt to Charles Barr for his interest in Fred O'Donovan and for so generously sharing his thoughts and knowledge. Special thanks are also due to Alain Kerzoncuf and La Cinémathèque de Toulouse, as well as Dudley Andrew, for essential research assistance in relation to Rebecca.

\footnotetext{
${ }^{71}$ See the discussion of camera style by Erin Sullivan, 'Stage versus screen: the RSC's Richard II', Digital Shakespeares, 4 December 2013; https://digitalshakespeares.wordpress.com/2013/12/04/stage-versus-screenthe-rscs-richard-ii/; accessed 22 September 2016.

72 Michael Barry, Memo, 13 March 1952, WAC L1/327.

73 'Mr Fred O'Donovan: Humour in the Theatre', The Times, 22 July 1952, p. 8.
} 